\title{
POTRET KEMISKINAN DAN ANAK PUTUS SEKOLAH DI DESA TEMMABARANG KECAMATAN PENRANG KABUPATEN WAJO
}

\author{
Muhlis M \\ Susdiyanto \\ Abd. Rasyid Masri \\ Guru Pendidikan Agama Islam SDN 147 Temmabarang \\ Email: muchlis.m1986@gmail.com
}

\begin{abstract}
Abstrak: Tulisan ini mengkaji tentang potret kemiskinan dan anak putus sekolah di desa Temmabarang Kecamatan Penrang Kabupaten Wajo. Jenis penelitian ini adalah jenis penelitian lapangan yang bersifat deskriptif kualitatif. Pendekatan yang digunakan adalah pendekatan fenomenologi. Sumber data dalam penelitian ini adalah anak-anak putus sekolah, orang tua yang memiliki anak-anak putus sekolah serta tokoh masyarakat di DesaTemmabarang Kecamatan Penrang Kabupaten Wajo. Pengumpulan data dilakukan dengan metode observasi, wawancara, dan dokumentasi. Instrumen dalam penelitian ini adalah peneliti itu sendiri dan dibantu dengan pedoman observasi, pedoman wawancara, dan dokumentasi dengan alat-alat bantu untuk mengumpulkan data seperti tape recorder, video kaset, atau kamera. Data dianalisis dengan teknik editing, kodefikasi data, dan triangulasi. Data diuji keabsahannya dengan perpanjangan keikutsertaan dan ketekunan pengamatan.

Potret kemiskinan dan anak putus sekolah di desa Temmabarang Kecamatan Penrang Kabupaten Wajo karena masih minimnya lahan yang bisa digarap untuk pertanian oleh masyarakat sehingga tidak memiliki penghasilan tetap, keberadaan lahan persawahan tidak menjamin karena tidak adanya irigasi, kebutuhan yang semakin hari semakin meningkat, dan tidak memiliki modal untuk berwirausaha serta kurangnya pengetahuan tentang pentingnya pendidikan.
\end{abstract}

\section{Keywords. Kemiskinan, Anak Putus Sekolah, Desa Temmabarang}

\section{PENDAHULUAN}

Kemiskinan yang dirasakan masyarakat di Indonesia pada umumnya dan di desa Temmabarang pada khususnya dapat diketahui dengan jelas dan pasti. Hal ini sudah jelas tampak dengan kesulitan masyarakat dalam memenuhi kebutuhan hidup mereka disemua aspek. Kebutuhan hidup yang semakin hari semakin meningkat, menyebabkan masyarakat lebih kesulitan dalam pemenuhan setiap kebutuhan hidup. Di samping itu, harga-harga kebutuhan sehari-hari yang terus melonjak. Pendukung penyebab kemiskinan adalah di mana masyarakat yang sangat kesulitan memperoleh pekerjaan, bagi yang telah bekerja hanya mendapatkan gaji kecil yang tidak dapat menutupi semua kebutuhan sehari-hari, adanya pengurangan karyawan sehingga yang berpendidikan rendah akan sangat sulit untuk memperoleh pekerjaan yang layak lagi.

Kemiskinan memang tidak bisa ditepis keberadaannya karena sangat banyak faktor yang pendukungnya. Namun sangat kurang mansyarakat yang mau memikirkan solusi untuk mengurangi angka kemiskinan, bahkan di kalangan pemerintahanpun 
demikian adanya. Dengan demikian, kemiskinan yang terjadi diseluruh wilayah di Indonesia ibaratnyanya pembagian sembako yang sifatnya merata dan semua masyarakat menengah kebawah pasti akan dapat. Mirisnya sekarang ini, kemiskinan bisa dikatakan sebagai ikon dan warisan untuk generasi berikutnya. Hal ini terbukti dengan fakta yang ada dilapangan, banyaknya anak-anak yang mengalami putus sekolah karena kemiskinan yang dialami oleh orangtua mereka, sehingga anak-anak yang merupakan generasi pelanjut pun ikut merasakan dampak dari kemiskinan karena mereka harus membantu orang tua untuk mencari nafkah demi memenuhi kebutuhan sehari-hari. Potret seperti ini tidak bisa dihindari dan yang semestinya masyarakat dan pihak pemerintah jangan menutup mata sebelah dengan apa yang dialami oleh masyarakat miskin, sebab jika generasi muda yang masa kecilnya seharusnya belajar, akan tetapi mereka pergunakan untuk bekerja membantu orang tua mereka demi memenuhi kebutuhan keluarga, maka secara tidak langsung kita telah memboyong lebih banyak lagi masyarakat kearah kemiskinan dan kebodohan yang seharusnya mereka dipelihara, dididik dengan baik agar menjadi generasi yang amanah penerus bangsa kelah.

Kemiskinan dengan pendidikan ibaratnya saudara kembar yang dikandung bersama dan lahirnya juga hanya berselang beberapa menit saja. Artinya, dimana ada kemiskinan, maka akan berpengaruh besar terhadap pendidikan dan dampak yang paling menonjol dari kemiskinan tersebut adalah pendidikan. Padahal secara teori, kita semua tau jika pendidikan itu sangatlah penting, karena dengan adanya pendidikan maka kita dapat mengetahui ilmu pengetahuan, dapat memiliki ketarampilan keterampilan, sopan santun, kesadaran pentingnya martabat, dan lain sebagainya.

Saat ini sudah banyak program yang telah dicanangkan oleh pemerintah untuk memberantas kemiskinan dengan harapan agar anak-anak tidak mengalami putus sekolah jika program tersebut ditinjau dari bidang pendidikan. Akan tetapi, perealisasiannya masih belum maksimal dan belum merata sampai kepelosok desa yang tersebar di Indonesia khususnya pada Desa Temmabarang. Program yang telah matang secara teori seharusnya selalu dievaluasi jika dalam pelaksanaannya masih kurang berhasil. Hal ini diharapkan agar dalam perealisasiannya selalu ada strategi dan cara baru untuk lebih meningkatkan usaha pemberantasan kemiskinan sehingga anak-anak yang merupakan pewaris bangsa dapat tumbuh dengan memperoleh pendidikan yang baik.

Pendidikan memang sangat penting dan sangat di butuhkan oleh semua masyarakat, baik pendidikan formal maupun non formal. Pendidikan sangat menunjang perbaikan taraf hidup kita. Pendidikan di artikan sebagai usaha yang di jalankan oleh seseorang atau kelompok orang lain agar menjadi dewasa atau mencapai tingkat hidup atau penghidupan yang lebih tinggi dalam arti mental. Saat ini, di Indonesia melakasanakan wajib belajar 9 tahun terhitung dari tingkat SD sampai SLTP. ${ }^{1}$ Dalam upaya mengentaskan dan memutuskan mata rantai kemiskinan, salah satu titik berat yang harus diberikan perhatian yang serius adalah anak-anak. Pemerintah seharusnya bisa menjamin dan memenuhi hak-hak mereka.

Terlebih lagi, kita harus menyadari dan merenungkan bahwa anak-anak merupakan titipan Sang Pencipta yang harus kita jaga dan rawat dengan baik. Oleh karenanya, upaya pengurangan kemiskinan juga harus difokuskan pada anak-anak

\footnotetext{
${ }^{1}$ Baharuddin, Psikologi Pendidikan: Reflektif Teoritis Terhadap Fenomena (Yogyakarta: Arruzz Media, 2007), h. 37.
} 
dengan menyediakan sarana sosial dasar (pendidikan dan kesehatan gratis) dengan kualitas yang baik bagi anak-anak yang merupakan kunci bagi mereka untuk membangun kapasilitas dasar mereka dalam rangka menjalani kehidupan dengan lebih bermartabat dan juga untuk menjamin kualitas generasi penerus keberlangsungan dan keberlanjutan hidup bangsa ini.

Kemiskinan sudah menjadi suatu fenomena yang selalu hangat untuk diperbincangkan di negara sedang berkembang, termasuk Indonesia. Memang tak mudah bagi suatu negara untuk mengetaskan penduduknya dari belenggu kemiskinan, butuh suatu kebijakan yang komprehensif dan berkesinambungan. Kemiskinan merupakan momok yang bagi semua orang, tak terkecuali bagi anak-anak. Bisa dikatakan anak-anak dari keluarga miskin merupakan korban sesungguhnya dari kebiadapan kemiskinan. Sebagian besar hak-hak dasar mereka sebagai anak-anak seperti pendidikan, kesehatan, maupun tempat tinggal yang layak, semuanya terampas karena mereka terlahir dari keluarga miskin. Seakan-akan kesempatan mereka untuk bisa menyenyam kehidupan yang layak dimasa mendatang semakin kecil lantaran hakhak dasar mereka sebagai anak yang notabene merupakan masa-masa tumbuh berkembang dirampas oleh kemiskinan. Lingkaran kemiskinan sudah bagaikan benang kusut yang sangat susah untuk diurai. Kemiskinan adalah warisan. Mungkin itu sangat cocok untuk menggambarkan fenomena kemiskinan.

Pendidikan merupakan kunci yang tergolong penting dalam proses perkembangan dalam memajukan suatu bangsa. Bisa dibahasakan bahwa jika tingkat pendidikan dalam suatu negara dikatakan termasuk kategori tinggi, setidaknya peradaban dan pola pikir masyarakat di negara tersebut haruslah tinggi pula. ${ }^{2}$

Adanya fenomena yang menjamur terjadi pada masyarakat di seluruh daerah di Indonesia ini yaitu fenomena putus sekolah yang tidak bisa terhindarkan karena hal tersebut sudah merupakan konsumsi umum meskipun merupakan masalah yang cukup serius di negeri ini. Pada fenomena kemiskinan yang menjadi tuas dalam hal anak-anak harus mengalami putus sekolah didasari oleh faktor internal dan faktor eksternal. Jika menilik lebih jauh, faktor internal berasal dari dalam diri anak itu sendiri, misalnya saja kurangnya minat untuk belajar atau menerima pelajaran, faktor-faktor psikologis dari diri anak. Faktor eksternal disini berkaitan dari luar diri anak, misalnya saja berkaitan dengan lingkungan, keluarga, ekonomi dan fasilitas serta sarana dan prasarana pendukung kegiatan belajar mengajar, serta kecanduan dalam mencari nafkah yang sudah sulit dihilangkan. ${ }^{3}$

Berdasarkan data yang diperoleh pada observasi awal di Desa Temmabarang Kecamatan Penrang Kabupaten Wajo, maka diketahui bahwa tingkat kemiskinan pada SDN 304 Temmabarang yaitu tahun 2015/2016 terdapat 2 orang anak put us sekolah, pada tahun 2016/2017 terdapat 4 orang anak putus sekolah dan 2017/2018 terdapat 4 anak yang putus sekolah. Selanjutnya di SDN 147 Temmabarang yaitu tahun 2015/2016 terdapat 3 orang anak putus sekolah, tahun 2016/2017 terdapat 4 orang anak putus sekolah, dan tahun 2017/2018 terdapat 4 anak yang mengalami putus sekolah. Sedangkan di SDN 416 Temmabarang pada tahun 2015/2016 terdapat 2 orang anak putus sekolah, tahun 2016/2017 terdapat 3 orang anak putus sekolah dan tahun 2017/2018 terdapat 4 anak yang mengalami putus sekolah yang masuk dalam kategori

\footnotetext{
${ }^{2}$ Fuad Ihsan, Dasar-Dasar Kependidikan (Jakarta: Rineka Cipta, 2008), h. 46.

${ }^{3}$ A Murni Yusuf, Kemiskinan dan Kebutuhan Pokok(Jakarta: CV. Rajawali, 2006), h. 53.
} 


\section{Potret Kemiskinan dan Anak Putus Sekolah di Desa Temmabarang...}

miskin. Dengan demikian, dapat diketahui bahwa setiap tahun selalu ada peningkatan kemiskinan di Desa Temmabarang Kecamatan Penrang Kabupaten Wajo.

Kemiskinan, merupakan factor masyarakat memilih untuk tidak menyekolahkan anaknya dan terpaksa memilih mengajak anaknya bekerja untuk membantu kedua orang tuanya. Kemiskinan yang dikarenakan rendahnya pendidikan orang tua dan rendahnya pengetahuan akan pentingnya pendidikan menjadikan sebagian masyarakat di negeri ini menjadikan pendidikan di sekolah formal sebagai kebutuhan sekunder. Kemudian akibat yang ditimbulkan dari permasalahan putus sekolah ini juga beragam, seperti kenakalan remaja, pengangguran dan lain-lain. Sehingga penulis tertarik dengan penelitian ini karena tingginya angka anak putus sekolah di SD yang disebabkan banyaknya orang tua siswa keluar daerah mencari nafkah karena rata-rata hanya bekerja sebagai buruh tani.

Tulisan ini akan mengkaji tentang potret kemiskinan dan anak putus sekolah di Desa Temmabarang Kecamatan Penrang Kabupaten Wajo.

\section{KAJIAN TEORITIK}

Kata "miskin" sering kali berdampingan dengan kata "fakir". Dalam Kamus Besar Bahasa Indonesia, kata kemiskinan, yang berakar kata "miskin" diartikan sebagai tidak berharta benda, serba kekurangan (berpenghasilan sangat rendah) dan kemiskinan berarti hal miskin atau keadaan miskin. ${ }^{4}$ Kata lain yang hampir sama menggambarkan keadaan seperti ini adalah "fakir" yang berarti orang yang sangat kekurangan, atau orang yang terlalu miskin, orang yang sengaja membuat dirinya dalam serba kekurangan untuk mencapai kesempurnaan batin. ${ }^{5}$

Dengan demikian, dapat diartikan bahwa orang miskin adalah orang yang kehidupannya identik dengan kefakiran dan mereka yang tergolong miskin tersebut merupakan orang yang sama sekali tidak mempunyai apa-apa, serta orang yang tidak memiliki sesuatu yang dapat mencukupi kebutuhan hidup mereka beserta keluarganya. Seorang dikatakan miskin karena situasi dan kondisi kehidupan mereka benar-benar sudah membatasi ruang geraknya sehingga menjadi sedikit dan sangat sempit lalu mencegahnya untuk bergerak. Orang miskin dapat juga diartikan bahwa orang yang hanya tinggal berdiam diri di rumah saja dan tidak ada keinginan ataupun niat untuk melakukan pekerjaan sebagai pengemis ataupun meminta-minta kepada orang lain.

Kondisi kemiskinan yang dialami oleh seseorang, seringkali dipahami sebagai suatu keadaan yang dialami seseorang seperti kekurangan uang dan barang untuk menjamin kelangsungan hidup. Kemiskinan itu dapat diartikan sebagai suatu ketidak mampuan dalam memenuhi berbagai kebutuhan seperti pangan, perumahan, pakaian, pendidikan, kesehatan, dan sebagainya. Kemiskinan adalah suatu kondisi yang dialami seseorang atau kelompok orang yang tidak mampu menyelenggarakan hidupnya sampai suatu taraf yang dianggap manusiawi. ${ }^{6}$

Menurut Suparlan kemiskinan merupakan sebagai suatu standar tingkat hidup yang rendah yaitu adanya tingkat kekurangan materi pada sejumlah atau golongan

\footnotetext{
${ }^{4}$ Departemen Pendidikan dan Kebudayaan, Kamus Besar Bahasa Indonesia (Jakarta: Balai Pustaka, 1990), h. 587.

${ }^{5}$ Ahmad Warson Munawwir, Kamus al-Munawwir Arab-Indonesia Terlengkap(Cet. 25; Surabaya: Pustaka Progressif, 2002), h. 464.

${ }^{6}$ Alfian, Kemiskinan Struktural: Suatu Bunga Rampai (Jakarta: Penerbit Yayasan Ilmu-ilmu Sosial dan HIPIS, 2000), h. 64.
} 
orang dibandingkan dengan standar kehidupan yang umum berlaku dalam masyarakat yang bersangkutan. Standar kehidupan yang rendah ini secara langsung tampak pengaruhnya terhadap tingkat keadaan kesehatan kehidupan moral, dan rasa harga diri dari mereka yang terolong sebagai orang miskin. Berikut akan diuraikan tentang faktor penyebab kemiskinan:

(1) Pendidikan yang tergolong sangat rendah

Seseorang yang memiliki pendidikan yang rendah bahkan dapat dikatakan tidak memiliki pendidikan dapat menyebabkan ia masuk dalam kategori orang-orang yang kurang bahkan tidak memiliki suatu keterampilan atau kompetensi khusus yang dapat dipergunakan didalam kehidupan mereka. Terbatasnya atau rendahnya suatu pendidikan atau keterampilan yang seseorang miliki dapat berdampak terhadap keterbatasan kemampuan serta kesempatan seseorang untuk dapat masuk dalam dunia kerja.

Kualitas pendidikan di Indonesia semakin memburuk. Terbukti dari kualitas guru, sarana belajar, dan murid-muridnya. Guru-guru tentuya punya harapan terpendam yang tidak dapat mereka sampaikan kepada siswanya. Guru-guru saat ini kurang kompeten. Banyak orang yang menjadi guru karena tidak diterima dijurusan lain atau kekurangan dana. Kecuali guru-guru lama yang sudah lama mendedikasikan dirinya menjadi guru. Selain berpengalaman mengajar murid, mereka memiliki pengalaman yang dalam mengenai pelajaran yang mereka ajarkan. Belum lagi masalah gaji guru. Jika fenomena ini dibiarkan berlanjut, tidak lama lagi pendidikan di Indonesia akan hancur mengingat banyak guru-guru berpengalaman yang pensiun.

Sarana pembelajaran juga turut menjadi faktor semakin terpuruknya pendidikan di Indonesia, terutama bagi penduduk di daerah terbelakang. Namun, bagi penduduk di daerah terbelakang tersebut, yang terpenting adalah ilmu terapan yang benar-benar dipakai buat hidup dan kerja. Ada banyak masalah yang menyebabkan mereka tidak belajar secara normal seperti kebanyakan siswa pada umumnya, antara lain guru dan sekolah.

Pada tahun 2014 posisi pendidikan Indonesia sangatlah buruk. The learning curve pearson 2014, sebuah lembaga pemeringkatan pendidikan dunia memaparkan bahwa Indonesia menempati peringkat terakhir dalam mutu pendidikan di dunia. Sedangkan di tahun 2015 mutu pendidikan di Indonesia masih saja berada di 10 negara yang memiliki mutu pendidikan yang rendah, peringkat tersebut di dapat dari global school ranking. Dilihat dari tahun 2014 berjalan ke tahun 2015 mutu pendidikan di Indonesia dapat dikatakan mengalami peningkatan, meskipun tidak mengalami peningkatan yang sangat signifikan. Merangkum dari beberapa sumber, dapat dikatakan bahwa ada empat faktor yang setidaknya menjadi penyebab rendahnya mutu pendidikan di Indonesia, yaitu: ${ }^{7}$

a. Pengunaan Buku Paket Sebagai Buku "Acuan"

Indonesia sudah beberapa kali mengganti kurikulum yang digunakan tetapi setiap terjadinya perubahan tersebut tidak menimbulkan kemajuan dari hal tersebut. Meskipun kurikulum diubah, tetapi sistem pengunaan buku acuan atau buku paket tetap saja digunakan dalam proses pembelajaran, guru-guru pun mengunakan buku tersebut menjadi acuan utama untuk mengajar tanpa ada referensi dari buku yang lainnya.

\footnotetext{
${ }^{7}$ Indonesia/https://pendidikberpena.wordpress.com/2014/12/05/catatan-buram-pendidikan-vspendidkan-berkualitas/
} 


\section{Potret Kemiskinan dan Anak Putus Sekolah di \\ Desa Temmabarang...}

\section{b. Sistem Pengajaran yang Monoton}

Sistem pembelajaran yang sama selalu di terapkan para guru untuk muridnya, dengan memberi peraturan bahwa selama guru menyampaikan materi, murid tidak di perbolehkan bertanya. Hal tersebut malah menjadikan anak murid malas bertanya dan justru tidak memperhatikan materi yang di sampaikan, tidak ada komunikasi yang aktif antara anak murid dengan guru.

\section{c. Kualitas Guru yang Rendah}

Bukan rahasia lagi bahwa para guru di Indonesia itu memiliki kualitas yang rendah, mereka lebih mementingkan mutu mereka sendiri dari pada keberhasilan para muridnya. Tuntutan dari pemerintah yang juga meminta sertifikasi lebih mendorong mereka untuk memanipulasi data, dan mementingkan adminitrasi sekolah, bagaimna cara pempertahankan murid, cara menarik murid-murid baru, agar ingin mendaftar ke sekolah tersebut.

d. Budaya Mencontek yang Semakin Menjadi

Budaya mencontek, sebenarnya bukanlah salah dari anaknya malas belajar, tetapi dari gurunya tidak dapat mengontrol kebiasaan anak seperti itu, yang lebih parahnya lagi, ada beberapa guru yang mengajarkan anak-anaknya untuk mencontek, seperti yang sering terdengar sekarang bahwa, setiap anak-anak kelas akhir di tingkat SMP maupun SMA, yang ingin ujian nasional di berikan bocoran kunci jawaban dari sekolah.

Dari beberapa faktor tersebut dapat terlihat sekali bahwa pendidikan di Indonesia sangat susah jika ingin diperbaiki, jika tidak ada perubahan yang benar-benar dilakukan untuk pendidikan di Indonesia. Dalam suatu website ada mengatakan bahwa Indonesia bukan lah negara pendidikan. Karena Indonesia tidak pernah memandang pendidikan adalah sesuatu yang penting di Indonesia. Dalam hal ini indonesia harus mengubah pandangan terhadap pendidikan di indonesia, karena dengan pendidikan,indonesia akan lebih bisa bersaing di dunia global pada saat ini. Dengan meningkatnya kualitas pendidikan berarti sumber daya manusia yang terlahir akan semakin baik mutunya dan akan mampu membawa bangsa ini bersaing secara sehat dalam segala bidang di dunia internasional.

(2) Kurangnya keinginan untuk bekerja

Bekerja bukan hanya semata-mata membutuhkan keterampilan seseorang, akan tetapi semangat dan motivasi internal dan eksternal tidaklah kala pentingnya harus dimiliki seseorang, sebab jika kurangnya minat dan keinginan untuk bekerja, maka seseorang tidak akan memiliki suatu penghasilan dan akan menggiring kearah kemiskinan. Maka jika seseorang ingin terhindar dari kemiskinan yang sudah mendera kebanyakan masyarakat, maka sangat penting seseorang untuk memiliki suatu motivasi yang kuat untuk bekerja.

Menurut Hasibuan, menjelaskan bahwa prestasi kerja adalah suatu hasil kerja yang dicapai seseorang dalam melaksanakan tugas-tugas yang dibebankan kepadanya dengan didasarkan atas kecakapan, pengalaman, kesungguhan, serta waktu. ${ }^{8}$ Hal ini

${ }^{8}$ Hasibuan, Sayuti. Ekonomi Sumberdaya Manusia: Teori dan Kebijakan (Jakarta: Pustaka LP3ES Indonesia, 1996), h. 27. 
juga sejalan dengan konsep tentang prestasi kerja merupakan suatu hasil yang dicapai oleh karyawan dalam mengerjakan tugas atau pekerjaannya secara efisien dan efektif. ${ }^{9}$

Pada suatu organisasi penilaian kerja merupakan faktor kunci dalam mengembangkan kemajuan perusahaan. Penilaian kerja individu sangat bermanfaat bagi dinamika pertumbuhan organisasi secara keseluruhan. Melalui penilaian tersebut, kondisi kerja karyawan dapat diketahui perkembangannya.

Hasil evaluasi prestasi kerja pada karyawan akan menghasilkan lima kriteria prestasi kerja yaitu prestasi kerja yang buruk, kurang, sedang, baik dan baik sekali. Setiap karyawan mampu menunjukkan prestasi kerja yang berbeda-beda meskipun jenis pekerjaan yang dikerjakan hampir sama. Prestasi kerja karyawan inilah yang nantinya digunakan oleh pimpinan perusahaan untuk membuat keputusan berkaitan dengan pemberian kesempatan kerja secara adil seperti promosi, kenaikan gaji, pemberhentian, rotasi atau pemindahan karyawan, perbaikan dan pengembangan karier dalam rangka untuk mencapai tujuan perusahaan. Selain itu, ada hal lain yang juga dapat membedakan antara karyawan satu dengan karyawan lainnya yaitu kepuasan kerja karyawan atas nilai-nilai (berbagai aspek) dari pekerjaannya. ${ }^{10}$

Ada tiga faktor yang berpengaruh terhadap prestasi kerja, yaitu: a. Faktor individu, meliputi: kemampuan, keterampilan, latar belakang keluarga, pengalaman kerja, tingkat sosial, dan demografi seseorang; b. Faktor psikologi, meliputi: persepsi, peran, sikap, kepribadian, motivasi dan kepuasan kerja; c. Faktor organisasi, meliputi: struktur organisasi, desain pekerjaan, kepemimpinan, dan sistem penghargaan (reward system). ${ }^{11}$

(3) Kurangnya sumber daya alam

Sumber daya alam bagi masyarakat sangat penting akan tetapi, jika sumber daya alam kurang disuatu daerah maka masyarakat akan dilanda kemiskinan karena tidak dapat memberikan suatu keuntungan bagi kelangsungan kehidupan mereka. Hal tersebut sejalan dengan kata bahwa masyarakat tersebut miskin jika sumber daya alamnya juga miskin. Dalam bukunya, ${ }^{12}$ Akhmad Fauzi membagi pemahaman terhadap sumber daya alam, kedalam dua pandangan yang berbeda, yaitu.

Pertama, pandangan konservatif atau sering disebut sebagai pandangan pesimis atau perspektif Malthusian. Dalam pandangan ini, resiko akan terkurasnya sumber daya alam menjadi perhatian utama. Dalam pandangan ini, sumber daya alam harus dimanfaatkan secara hati-hati karena karena ada faktor ketidakpastian terhadap apa apa yang akan terjadi terhadap sumber daya alam untuk generasi yang akan datang. Pandangan ini berakar pada pemikiran Malthus yang dikemukakan sejak tahun 1879 ketika bukunya yang tersohor itu, Principle of Population diterbitkan. Dalam perspektif Malthus, sumber daya alam yang jumlahnya terbatas ini tidak akan mampu mendukung pertumbuhan penduduk yang cenderung tumbuh secara eksponensial. Sementara produksi dari sumber daya alam akan mengalami apa yang disebut dalam teori konvensional sebagai diminishing return dimana output perkapita akan mengalami kecenderungan yang menurun sepanjang waktu. Menurut Malthus, ketika

\footnotetext{
${ }^{9}$ Dewa Ketut Sukardi. Psikologi Pemililhan Karier (Jakarta : PT. Rineka Cipta, 2004), h. 16-50.

${ }^{10}$ Osborn dan Plastrik. Manajemen Sumber Daya Mausia (Yogyakarta: BPFE, 2002), h. 20.

${ }^{11}$ Sondang P. Siagian, Kiat Meningkatan Produktifitas Kerja (Jakarta: Rineka Cipta, 2002), h. 53.

${ }^{12}$ Akhmad Fauzi, Ekonomi Sumberdaya Alam dan Lingkungan: Teori dan Aplikasi (Jakarta: PT. Gramedia Pustaka Utama, 2004), h. 35.
} 
proses diminishing return ini terjadi, standar hidup juga akan menurun sampai ke tingkat subsisten yang pada gilirannya akan mempengaruhi reproduksi manusia.

Pandangan kedua, adalah pandangan eksploitatif atau sering juga disebut sebagai perspektif Ricardian. Dalam pandangan ini dikemukakan antara lain:

a. Sumber daya alam (SDA) dianggap sebagai mesin pertumbuhan (engine of growth) yang mentransformasikan sumber daya ke dalam man-made capital yang pada gilirannya akan menghasilkan produktifitas yang lebih tinggi di masa datang.

b. Keterbatasan supply dari sumber daya untuk memenuhi kebutuhan ekonomi dapat disubstitusikan dengan cara intensifikasi (eksploitasi sumber daya secara intensif) atau dengan cara ekstensifikasi (memanfaatkan sumber daya yang belum dieksploitasi).

Jika sumber daya menjadi langka, hal ini akan tercermin dalam dua indikator ekonomi, yakni meningkatnya baik itu harga output maupun biaya ekstraksi per satuan output. Meningkatnya harga output akibat meningkatnya biaya per satuan output akan menurunkan permintaan terhadap barang dan jasa yang dihasilkan sumber daya alam. Di sisi lain, peningkatan harga output menimbulkan insentif kepada produsen sumber daya alam untuk berusaha meningkatkan supply. Namun, karena ketersediaan sumber daya alam sangat terbatas, kombinasi dampak harga dan biaya akan menimbulkan insentif untuk mencari sumber daya substitusi dan peningkatan daur ulang. Selain itu, untuk mengembangkan inovasi-inovasi seperti pencarian deposit baru, peningkatan efisiensi produksi, dan peningkatan teknologi daur ulang sehingga dapat mengurangi tekanan terhadap pengurasan sumber daya alam.

Kemudian dalam hirarki konseptual, sumber daya alam merupakan barang publik (public goods). Konsekuensi atas konsepsi ini adalah bahwa akses untuk mendapatkannya harus terbuka untuk sebanyak mungkin pelaku ekonomi dan masyarakat luas. Jenis public goods seperti ini harus dikelola secara transparan dan diawasi secara terbuka. Dengan demikian, jika kendali pengelolaannya dilakukan pemerintah saja tanpa kontrol yang memadai dari pihak masyarakat, maka kemanfaatannya menjadi sangat terbatas pula. Pengalaman Indonesia selama ini memperlihatkan bahwa kontrol pemerintah pusat sangat kuat sehingga kemanfaatannya pun terbatas pada kalangan dekat birokrasi pusat tersebut. Hal ini terbukti dari alokasi berbagai potensi sumber daya alam seperti pertambangan, hutan, perikanan dan sebagainya. ${ }^{13}$

(4) Kurangnya lapangan pekerjaan

Lapangan pekerjaan yang kurang dapat mengakibatkan kemiskinan bagi masyarakat disuatu daerah. Akan tetapi, jika seseorang mampu menciptakan lapangan pekerjaan baru, maka akan lebih baik untuk kelangsungan hidup suatu keluarga sedangkan faktanya saat sekarang ini, hal tersebut sangat mustahil dilakukan bagi masyarakat miskin karena terkendala pada modal dan keterampilan.

Lapangan pekerjaan merupakan wahana yang sangat penting bagi para tenaga kerja untuk mengeksplorasi kemampuan diri dalam bidang tertentu. Fenomena semakin banyaknya jumlah angkatan kerja yang siap kerja tidak mampu diimbangi dengan lapangan pekerjaan yang tersedia. Dalam pasar kerja telah terjadi meningkatnya

${ }^{13}$ Rachbini J, Didik. Politik Ekonomi Baru Menuju Demokrasi Ekonomi (Jakarta: Grasindo, 2001), h. 54. 
penawaran kerja daripada permintaan kerja, maka terjadi adanya selisih antara penawaran dan permintaan kerja yang mengakibatkan terciptanya pengangguran. Bagi angkatan kerja lapangan pekerjaan merupakan sumber utama pendapatan untuk memenuhi kebutuhan hidup sehari-hari. Besar atau kecilnya pendapatan yang diperoleh dari lapangan pekerjaan tersebut menentukan kesejahteraan bagi tenaga kerja serta keluarganya.

Menurut Hasibuan menyatakan bahwa jika terdapat pengangguran dalam suatu masyarakat hal ini berarti kurang efisiennya pemanfaatan salah satu modal dasar dan dibatasinya pilihan yang tersedia. ${ }^{14}$ Bahkan jika pengangguran itu sudah cukup tinggi, hal itu dapat mengganggu stabilitas ekonomi masyarakat yang bersangkutan. Pengangguran yang tinggi bukan hanya menjadi masalah dalam bidang ekonomi saja tapi juga menjadi masalah dalam bidang sosial yang dimana individu menganggur tersebut kehilangan akan kepercayaan dirinya dan berbuat tindakan kriminal. Menurut Sukirno pengangguran adalah jumlah tenaga kerja dalam perekonomian yang secara aktif mencari pekerjaan tetapi belum memperolehnya. ${ }^{15}$

(5) Minimnya modal usaha

Kemiskinan disebaban oleh beberapa faktor termasuk minimnya modal usaha yang dimiliki oleh seseorang. Meskipun telah memiliki suatu keterampilan yang besar, akan tetapi modal juga tidak kalah pentingnya sebab akan dipergunakan untuk melengkapi alat maupun bahan dalam rangka menerapkan keterampilan yang mereka miliki dengan suatu tujuan untuk memperoleh penghasilan.

Pengertian "modal usaha adalah uang yang dipakai sebagai pokok (induk) untuk berdagang, melepas uang, dan sebagainya; harta benda (uang, barang, dan sebagainya) yang dapat dipergunakan untuk menghasilkan sesuatu yang menambah kekayaan". ${ }^{16}$

Modal dalam pengertian ini dapat diinterpretasikan sebagai sejumlah uang yang digunakan dalam menjalankan kegiatan-kegiatan bisnis. Banyak kalangan yang memandang bahwa modal uang bukanlah segala-galanya dalam sebuah bisnis. Namun perlu dipahami bahwa uang dalam sebuah usaha sangat diperlukan. Yang menjadi persoalan di sini bukanlah penting tidaknya modal, karena keberadaannya memang sangat diperlukan, akan tetapi bagaimana mengelola modal secara optimal sehingga bisnis yang dijalankan dapat berjalan lancar. ${ }^{17}$

Teori modal dicetuskan pertama kali oleh Piere Bourdieu. Disebutkan bahwa teori ini mempunyai ikatan erat dengan persoalan kekuasaan. Oleh karenanya pemikiran Bourdieu terkonstruk atas persoalan dominasi. Dalam masyarakat politik tentu persoalan dominasi adalah persoalan utama sebagai salah satu bentuk aktualisasi kekuasaan. Pada hakikatnya dominasi dimaksud tergantung atas situasi, sumber daya (kapital) dan strategi pelaku. ${ }^{18}$ Bourdieu sebagai teoritisi sosial memiliki pengalaman yang luar biasa. Dari apa yang menjadi latar belakang hidupnya menjadikan Bourdieu

\footnotetext{
${ }^{14}$ Hasibuan, Sayuti. Ekonomi Sumberdaya Manusia: Teori dan Kebijakan (Jakarta: Pustaka LP3ES Indonesia 1996), h. 99.

${ }^{15}$ Sadono Sukirno,. Teori Mikro Ekonomi (Cetakan Keempat Belas Jakarta: Rajawali. Press, 2004), h. 28

${ }^{16}$ Ardi Nugroho, Listyawan, Pengaruh Modal Usaha (Yogyakarta: Pustaka Pelajar, 2011), h. 9. 2005), h. 7 .

${ }^{17}$ Amirullah, dan Imam Hardjanto, Pengantar Bisnis, Edisi Pertama (Yogyakarta: Graha Ilmu,

${ }^{18}$ Abd. Halim, Politik Lokal; Pola, Aktor \& Alur Dramatikalnya (Yogyakarta: LP2B, 2014), h. 108 .
} 


\section{Potret Kemiskinan dan Anak Putus Sekolah di Desa Temmabarang...}

menolak paradigma objektivisme dan subjektivisme walaupun tidak keseluruhan. Tetap ada elemen paradigma tersebut yang diilhami sebagai pembentuk atas teorinya. Namun bukan berarti teori yang dibangun berangkat atas paradigma dualisme antara struktur dengan agen seperti apa yang disebutkan dalam pandangan Anthony Giddens, Margaret Archer, dan Peter L. Berger. Tetapi lebih dari itu, Bourdieu membangun teorinya berdasarkan paradigma strukturalisme genetik. Paradigm ini mempunyai ciri khas internalisasi eksternalitas dan eksternalisasi internalitas dalam pandangan struktur dan agen. ${ }^{19}$

Konsepsi atas teori modal Bourdieu tidak bisa dilepaskan dari konsep dominasi lainnya. Sehingga pemikiran Bourdieu ini ada keterkaitan dengan konsep kekuasaan yang lain, yakni habitus \& ranah (Arena). Habitus dalam teori sosiologi dimaksudkan sebagai struktur mental kognitif yang menghubungkan manusia dengan dunia sosial. Manusia dianggap dibekali dengan serangkaian skema terinternalisasi yang digunakan untuk melahirkan persepsi, pemahaman, apresiasi, dan evaluasi atau kemampuan menilai terhadap dunia sosial. ${ }^{20}$

(6) Tanggung jawab terhadap keluarga

Bagi yang telah memiliki anggota keluarga dengan jumlah anggota keluarga yang tergolong banyak jika tak diimbangi dengan adanya usaha untuk meningkatkan penghasilan maka dapat mengakibatkan kemiskinan karena semakin banyak anggota keluarga akan semakin meningkat dan banyaknya kebutuhan hidup keluarga yang harus dipenuhi. $^{21}$

Menurut Sumodiningrat klasifikasi kemiskinan ada lima kelas, yaitu:

a. Kemiskinan Absolut

Kemiskinan absolut jika dipandang dari pemenuhan kebutuhan dasar tergolong minimum sehingga bisa saja salah satu orang bisa merasakan namanya hidup yang layak, sehingga jika dipandang berdasarkan tingkat pendapatan dalam pemenuhan kebutuhan. Berdasarkan hal tersebut, tingkat pendapatan yang tergolong rendah dapat menjadi pembatas antara kondisi yang tergolong miskin. Orang yang masuk dalam kategori miskin absolut jika penghasilannya berada dibawah standar kemiskinan, sehingga tidak dapat mencukupi kebutuhan hidup sehari-hari, seperti contohnya kebutuhan pangan, kebutuhan sandang, kebutuhan kesehatan, kebutuhan papan dan kebutuhan pendidikan.

Orang yang masuk dalam kategori miskin absolut termasuk miskin yang tidak mengacu atau tidak didasarkan pada garis kemiskinan. Dengan demikian, Kemiskinan yang absolut merupakan derajat dari kemiskinan yang berada pada garis bawah, dimana kebutuhan-kebutuhan yang mendasar dan termasuk dalam kategori kebutuhan yang minimum untuk bertahan hidup tidak dapat terpenuhi dengan baik. ${ }^{22}$

b. Kemiskinan Relatif

Dalam suatu kelompok masyarakat yang tergolong dalam kategori kemiskinan relatif jika penghasilannya lebih rendah jika dibandingkan dengan kelompok

\footnotetext{
${ }^{19}$ Nanang Krisdinanto, "Pierre Bourdieu, Sang Juru Damai", Jurnal KANAL, Vol. 2 No. 2 (Maret 2014), 194-197.

${ }^{20}$ George Ritzer \& Douglas J. Goodman, Teori Sosiologi; Dari Teori Sosiologi Klasik sampai Perkembangan Mutakhir Teori Sosial Postmodern (Yogyakarta: Kreasi Wacana, 2009), h. 581.

${ }^{21}$ Suparlan, P, Kemiskinan di Perkotaan: Bacaan untuk Antropologi Perkotaan (Jakarta: Sinar Harapan, 2000), h. 75.

${ }^{22}$ Tambunan, T. Perekonomian Indonesia Sejak Orde Lama Hingga Pasca Krisisi (Jakarta: Pustaka Quantum, 2006), h. 48.
} 
masyarakat lain tapi tidak memperhatikan apakah mereka termasuk dalam kategori miskin absolut atau tidak. Inti dalam hal kemiskinan yang relatif adalah adanya selisih yang sangat jauh pendapatan dalam masyarakat antara yang kaya dengan yang miskin. Suatu kemiskinan yang relatif dalam menunjukkan selisih pendapatan yang dapat berguna dalam hal mengukur ketimpangan dalam suatu daerah. Kemiskinan yang relatif juga bisa dipergunakan untuk mengukur suatu ketimpangan antar daerah yang dilakukan pada salah satu daerah tertentu. Pengukuran yang relatif harus berdasarkan pada tingkat pendapatan, selisih antara sumber daya alam serta sumber daya manusia berupa kualitas pendidikan, kesehatan, dan perumahan.

c. Kemiskinan Struktural

Kemiskinan struktural yang mengacu pada suatu sikap seseorang ataupun pada masyarakat yang disebabkan oleh suatu faktor budaya yang tidak mampu berusaha dalam hal membenahi suatu tingkat kehidupan walaupun adanya usaha yang dilakukan oleh pihak dari luar untuk dapat membantu mereka. Alfian memberikan pengertian tentang kata kemiskinan struktural merupakan suatu kemiskinan yang dialami oleh suatu golongan masyarakat sebab struktur sosial dalam kelompok masyarakat tidak dapat ikut menggunakan sumber pendapatan yang sebenarnya tersedia bagi mereka. ${ }^{23}$ Miskin yang struktural dapat meliputi yaitu kurangnya fasilitas pemukiman sehat, kekurangan pendidikan, kekurangan komunikasi dengan dunia sekitarnya.

Kemiskinan yang struktural dapat juga diukur dari kurangnya suatu perlindungan dari pihak hukum dan pemerintah sebagai birokrasi atau peraturan resmi yang dapat mencegah orang dalam memanfaatkan kesempatan yang ada.

\section{d. Kemiskinan Kronis}

1) Pemicu dalam hal kemiskinan kronis dapat disebabkan oleh beberapa hal, diantaranya adalah kondisi sosial budaya yang menjadi pemicu suatu sikap dan kebiasaan dalam suatu hidup di masyarakat yang tidak lancar.

2) Terbatasnya suatu sumber daya dan suatu keterasingan dengan bahasa lain terisolasi (daerah-daerah yang kritis akan sumber daya alam dan daerah terpencil).

3) Kurangnya tingkat pendidikan serta perawatan kesehatan, kurangnya lapangan pekerjaan dan tidak adanya daya oleh warga masyarakat untuk mengikuti perekonomian di pasar.

4) Penyebab terjadinya kemiskinan diakibatkan adanya: 1) adanya perubahan ekonomi dari normal ke arah krisis, 2) adanya perubahan bergantian dan musiman,dan 3) terjadinya suatu bencana alam ataupun akibat dari sesuatu yang mengakibatkan penurunan tingkat kesejahteraan kehidupan suatu masyarakat. ${ }^{24}$

a) Miskin Menurut Islam

Kemiskinan adalah keadaan dimana terjadi ketidak mampuan untuk memenuhi kebutuhan dasar seperti makanan, pakaian, tempat berlindung, pendidikan, dan kesehatan. Terdapat beberapa ayat yang menjelaskan tentang masalah kemiskinan serta solusi dalam mengatasi masalah tersebut. Akan tetapi, didalam al-Qur'an dan hadis tidak ada ditemukan bahwa ketetapan angka tertentu lagi sebagai fakir atau miskin serta yang harus diberikan bantuan. Maka dari itu, definisi dari kata miskin tergantung pada ijtihad manusia yang senantiasa berubah dari masa kemasa, sebab

\footnotetext{
${ }^{23}$ Alfian. Kemiskinan Struktural: Suatu Bunga Rampai,... h. 51.

${ }^{24}$ Sumodiningrat, G. Kemiskinan: Teori, Fakta dan Kebijakan (Jakarta: IMPAC, 2000), h. 63.
} 


\section{Potret Kemiskinan dan Anak Putus Sekolah di Desa Temmabarang...}

yang menjadi tolak ukurnya yaitu untuk merumuskan suatu makna yang abstrak (seperti kemiskinan, misalnya) selalu beruba-ubah. ${ }^{25}$

Para ahli fiqih brselisih pandangan tentang pengertian fakir dan miskin, pendapat yang paling jelas dalam hal ini adalah, yang di maksud fakir adalah seseorang yang sangat membutuhkan uluran tangan, akan tetapi mereka tidak ada niat untuk menjadi seorang pengemis ataupun sejenisnya, sedangkan miskin merupakan orang yang sangat butuh pertolongan sesama dan rela menjadi seorang pengemis untuk mendapatkan bantuan dan belas kasihan dari orang lain.

Sedangkan menurut jumhur ulama, fakir merupakan seseorang yang tak mempunyai harta benda atau hanya memiliki kurang dari separuh kebutuhan diri dan tanggungannya, sedangkan orang miskin merupakan seseoran yang memiliki separuh kebutuhannya atau lebih, tetapi tidak mencukupi. ${ }^{26}$

Kemiskinan dapat disebabkan oleh kelangkaan alat pemenuh kebutuhan dasar, ataupun sulitnya akses terhadap pendidikan dan pekerjaan. Menurut Suharto, kemiskinan struktural adalah kemiskinan yang terjadi bukan dikarnakan ketidak mampuan simiskin untuk bekerja (malas), melainkan karna ketidak mampuan sistem dan struktur sosial dalam menyediakan kesempatan-kesempatan yang memungkinkan simiskin dapat bekerja. ${ }^{27}$ Sedangkan menurut Didik J. Rachbini, secara teoritis, kemiskinan struktural dapat diartikan sebagai suasana kemiskinan yang dialami oleh suatu masyarat yang penyebab utamanya bersumber dari struktural sosial yang berlaku di sekitarnya sehingga mereka yang termasuk kedalam golongan miskin tampak tidak berdaya untuk mengubah nasibnya dan tidak mampu memperbaiki hidupnya. ${ }^{28}$

Kemiskinan merupakan masalah global, sebagian orang memahami istilah ini secara subyektif dan komparatif, sementara yang lainnya melihatnya dari segi moral dan evaluative, serta yang lainnya lagi memahaminya dari sudut ilmiah yang telah mapan. Kemiskinan adalah suatu keadaan di mana seseorang atau sekelompok tidak dapat memenuhi kebutuhannya secara maksimal disebabkan tidak produktif dan penghasilan yang tak mencukupi. Kemiskinan menurut Suparlan, didefinisikan sebagai standar tingkat hidup yang rendah, yaitu adanya suatu tingkat kekurangan materi pada sejumlah atau golongan orang dibandingkan dengan standar hidup yang berlaku dalam masyarakat bersangkutan. ${ }^{29}$ Hamdar Arraiyyah menerangkan bahwa al-Qur'an mengemukakan tiga jenis kemiskinan, yaitu: (a) kemiskinan materi; (b) kemiskinan jiwa (rohani); dan (c) kemiskinan dalam arti khusus, yakni kebutuhan manusia terhadap penciptanya.

\section{METODOLOGI PENELITIAN}

Jenis penelitian ini adalah jenis penelitian lapangan yang bersifat deskriptif kualitatif. Pendekatan yang digunakan adalah pendekatan fenomenologi. Sumber data dalam penelitian ini adalah anak-anak putus sekolah, orang tua yang memiliki anak-

${ }^{25}$ Maulana Musa Ahmad Olgar, Mendidik Anak Secara Islami, Terjemahan Supriyoto Abdullah Hidayat (Yogyakarta: Ash-Shatt, 2000), h. 56. h. 115 .

${ }^{26}$ Yusuf Qardhawi, Kiat Islam Mengentaskan Kemiskinan (Jakarta: Gema Insani Press, 1995),

${ }^{27}$ Suharto. E, Membangun Masyarakat Memberdayakan Rakyat (Bandung: Refika Aditama, 2008), h. 18.

${ }^{28}$ Didik J. Negara dan Kemiskinan Daerah (Jakarta: Pustaka Sinar Harapan, 1995), h. 15.

${ }^{29}$ Persudi Suparlan, Kemiskinan di Perkotaan (Jakarta: Yayasan Obor, 1993), h. 11. 
anak putus sekolah serta tokoh masyarakat di DesaTemmabarang Kecamatan Penrang Kabupaten Wajo. Pengumpulan data dilakukan dengan metode observasi, wawancara, dan dokumentasi. Instrumen dalam penelitian ini adalah peneliti itu sendiri dan dibantu dengan pedoman observasi, pedoman wawancara, dan dokumentasi dengan alat-alat bantu untuk mengumpulkan data seperti tape recorder, video kaset, atau kamera. Data dianalisis dengan teknik editing, kodefikasi data, dan triangulasi. Data diuji keabsahannya dengan perpanjangan keikutsertaan dan ketekunan pengamatan.

\section{HASIL PENELITIAN DAN PEMBAHASAN}

Kemiskinan dinilai menjadi penyebab utama kasus anak putus sekolah di Desa Temmabarang Kecamatan Penrang Kabupaten Wajo. Hal itu berdampak pada ketersediaan pangan di tingkat keluarga yang dipengaruhi oleh daya beli suatu keluarga yang rendah. Berdasarkan observasi yang telah dilakukan pada tanggal 8 Januari 2018 ditemukan data anak yang mengalami putus sekolah karena faktor kemiskinan di Desa Temmabarang Kabupaten Wajo:

Tabel 13

Anak Putus Sekolah pada SDN di Desa Temmabarang Kabuaten Wajo

\begin{tabular}{|c|c|c|c|c|}
\hline \multirow{2}{*}{ No } & Tahun & \multicolumn{3}{|c|}{ SDN Desa Temmabarang } \\
\cline { 3 - 5 } & & SDN 416 & SDN 304 & SDN 147 \\
\hline 1 & $2015 / 2016$ & 2 anak & 2 anak & 3 anak \\
\hline 2 & $2016 / 2017$ & 3 anak & 4 anak & 4 anak \\
\hline 3 & $2017 / 2018$ & 4 anak & 4 anak & 4 anak \\
\hline
\end{tabular}

Sumber: Dokumen Kantor Desa Temmabarang Kecamatan Penrang Kabupaten Wajo

Berdasarkan tabel yang telah diuraikan di atas, maka diketahui bahwa anak yang mengalami putus sekolah semakin meningkat setiap tahunannya. Pada tahun 2015/2016 diketahui anak yang putus sekolah berdasarkan kualifikasi kemiskinan yaitu untuk miskin absolut sebanyak 2 anak, miskin relatif sebanyak 2 anak, miskin struktural sebanyak 4 anak, dan miskin kronis sebanyak 3 anak. Pada tahun 2016/2017 diketahui bahwa yang miskin absolut sebanyak 3 anak, miskin relatif sebanyak 2 anak, miskin struktural sebanyak 3 anak, dan miskin kronis sebanyak 4 anak. Selanjutnya pada tahun 2017/2018 diketahui anak yang putus sekolah berdasarkan kualifikasi kemiskinan yaitu untuk miskin absolut sebanyak 3 anak, miskin relatif sebanyak 4 anak, miskin struktural sebanyak 4 anak, dan miskin kronis sebanyak 4 anak.

Berdasarkan data jumlah anak yang mengalami put us sekolah selama tiga tahun terakhir, maka penulis mengamati pula faktor penyebab anak mengalami putus sekolah. Berikut datanya akan diuraikan kedalam bentuk tabel:

Tabel 14

Faktor Penyebab Anak Putus Sekolah

\begin{tabular}{|c|l|c|}
\hline No & \multicolumn{1}{|c|}{ Faktor Penyebab Putus Sekolah } & Jumlah \\
\hline 1 & Latar belakang pendidikan orang tua & 5 anak \\
\hline 2 & Lemahnya ekonomi keluarga/kemiskinan & 17 anak \\
\hline 3 & Kurangnya minat untuk bersekolah & 6 anak \\
\hline 4 & Kondisi lingkungan tempat tinggal & 2 anak \\
\hline \multicolumn{2}{|c|}{ Jumlah } & 30 anak \\
\hline
\end{tabular}

Sumber: Dokumen Kantor Desa Temmabarang Kecamatan Penrang Kabupaten Wajo 


\section{Potret Kemiskinan dan Anak Putus Sekolah di Desa Temmabarang...}

Berdasarkan tabel yang telah dikemukakan di atas, maka dapat diketahui bahwa faktor penyebab anak putus sekolah ada bermacam-macam yaitu; anak putus sekolah karena latar belakang pendidikan orang tua ada 5 anak, anak putus sekolah karena lemahnya ekonomi keluarga/kemiskinan ada 17 anak, anak putus sekolah karena kurangnya minat untuk bersekolah ada 6 anak, dan anak putus sekolah karena kondisi lingkungan tempat tinggal ada 2 anak. mencakup:

Kemiskinan dipahami dalam berbagai cara yang pemahaman utamanya

1. Gambaran kekurangan materi, yang biasanya mencakup kebutuhan pangan sehari-hari, sandang, perumahan, dan pelayanan kesehatan. Kemiskinan dalam arti ini dipahami sebagai situasi kelangkaan barang-barang dan pelayanan dasar. Berdasarkan observasi yang dilakukan pada tanggal 9 Januari 2018 pukul 15.00, ditemukan bahwa masih ada 2019 jiwa warga di Desa Temmabarang yang termasuk dalam kategori miskin. Hal ini didukung dengan adanya wawancara dengan kepala Desa Temmabarang Andi Page, yang mengatakan bahwa:

Jika kita mau melihat secara lebih detail masalah kekurangan materi, memang tergolong masih banyak. Akan tetapi, jika hanya melihat sepintas, maka kita kurang mengetahui bagaimana perekonomian warga disini. Jika masalah anakanak yang putus sekolah di tingkat sekolah dasar, jika ditinjau dari segi materi, memang masih ada beberapa keluarga yang anaknya harus putus sekolah. ${ }^{30}$

Pada kesempatan yang bersamaan, setelah melalukan wawancara dengan kepala Desa Temmabarang, selanjutnya melakukan wawancara dengan Nyompa selaku kepala Dusun Mattirowalie. Beliau ditemui dikediamannya pada pukul 17.15. beliau menjelaskan bahwa:

Setiap keluarga mempunyai kebutuhan yang berbeda-beda sehingga kita tidak bisa mengukur atau beranggapan bahwa jika dalam keluarga tersebut sudah memiliki anggota keluarga yang berpenghasilan, maka itu belum bisa dikategorikan bukan miskin dan tidak ada jaminan untuk anak-anak mereka tidak putus sekolah. Maka tidak bisa dipungkiri bahwa masih ada anak-anak di sini yang mengalami putus sekolah pada tingkat sekolah dasar. ${ }^{31}$

Wawancara selanjutnya dilakukan dengan salah satu warga yang menjelaskan tentang kemiskinan yang menjadi faktor sehingga anak-anak harus putus sekolah pada tingkat sekolah dasar, bahwa:

Jika masalah materi yang dibahas, maka kami dapat memastikan bahwa tidak akan pernah cukup karena setiap hari, makin meningkat juga kebutuhan yang harus dipenuhi, sehingga terkadang kebutuhan sekolah anak-anak kadang terlupakan dan tidak dapat terpenuhi. Nah disinilah terkadang ada keluarga yang tidak mampu memenuhi kebutuhan materi untuk anak-anaknya sehingga akibatnya anak-anak harus putus sekolah dan membantu orang tua bekerja untuk memenuhi kebutuhan materi keluarga. ${ }^{32}$

Hal tersebut seiring dengan penjelasan yang diperoleh dari Muh. Akbar selaku tokoh masyarakat, bahwa:

Memang masalah kebutuhan materi belum bisa teratasi dengan baik. Dan masalah anak yang putus sekolah tidak bisa dipungkiri dikarenakan setiap

\footnotetext{
${ }^{30}$ Andi Page, Kepala Desa Temmabarang, Wawancara, pada tanggal 9 Januari 2018.

${ }^{31}$ Nyompa, Kepala Dusun Mattirowalie, Wawancara, pada tanggal 11 Januari 2018.

${ }^{32}$ Dg. Mamala, Warga Desa Temmabarang, Wawancara, pada tanggal 12 Januari 2018.
} 
keluarga memiliki pemahaman masing-masing. Kebanyakan orang tua merasa pusing dan putus asa sehingga jalan keluar yang menurut mereka baik adalah dengan memberhentikan anak-anak dari sekolah dan membantu orang tua untuk mencari nafkah. ${ }^{33}$

Pendidik merupakan orang tua kedua bagi peserta didik. Setelah anak-anak meninggalkan rumah dan masuk di lingkungan sekolah, maka yang bertanggung jawab terhadap mereka adalah para pendidik yang ada di sekolah. Disinilah pendidik dikatakan sebagai orang tua kedua bagi anak-anak. Berdasarkan penelitian yang di lakukan di Desa Temmabarang ini, karena masalah yang diangkat adalah dampak kemiskinan pada pendidikan dasar, maka perlu adanya data dan keterangan yang mendukung dari pihak pendidik tentang hal tersebut. Berhubung yang akan menjadi pembahasan adalah hanya pendidikan pada tingkat dasar, maka data yang dikumpulkan juga hanya data pendidik di SD saja. Berikut data pendidik yang menjadi responden saat penelitian demi memperoleh data yang valid:

Tabel 15

Keadaan Pendidik Sekolah Dasar Negeri 416 Temmabarang

\begin{tabular}{|c|l|c|c|c|c|}
\hline No & \multicolumn{1}{|c|}{ Nama } & $\begin{array}{c}\text { Gol./ } \\
\text { Ruang }\end{array}$ & $\begin{array}{c}\text { Jabatan } \\
\text { Guru }\end{array}$ & $\begin{array}{c}\text { Tugas } \\
\text { Mengajar }\end{array}$ & KET \\
\hline 1. & Sufriati, S.Pd & III/b & Kepsek & Kelas IV-VI & PNS \\
\hline 2. & Nursaflinda & - & Guru Kelas & Kelas VI & GT \\
\hline 3. & Hj. Andi Ati, S.Pd & II/a & Guru Kelas & Kelas V & PNS \\
\hline $4 .$. & Sukma S.Pd.SD. & II/a & Guru Kelas & Kelas IV & PNS \\
\hline 5. & Andi Firdayanti & - & Guru Kelas & Kelas III & GT \\
\hline 6. & Andi Wildayanti & - & Guru kelas & Kelas II & GT \\
\hline 7. & Andi Elviani & - & Guru kelas & Kelas I & GT \\
\hline 8. & Ambo Dalle & - & Pustakawan & - & PT \\
\hline 9. & Suriadi & - & Bujang & - & PT \\
\hline
\end{tabular}

Sumber: Dokumen SDN 416 Temmabarang Kecamatan Penrang Kabupaten Wajo

Dari tabel di atas, dapat diketahui bahwa di SDN 416 Temmabarang Kecamatan Penrang Kabupaten Wajo terdapat 9 tenaga pendidik dengan uraian yaitu Ibu Sufriati selaku kepala SDN 416 Temmabarang, Ibu Nursaflinda selaku guru kelas VI, Ibu Hj. Andi Ati selaku guru kelas V, Ibu Sukma selaku guru kelas IV, Ibu Andi Firdayanti selaku guru kelas III, Ibu Andi Wildayanti selaku guru kelas II, Ibu Andi Elviani selaku guru kelas I, Pak Ambo Dalle selaku pustakawan, Pak Suriadi selaku bujang sekolah.

Tabel 16

Keadaan Pendidik Sekolah Dasar Negeri 147 Temmabarang

\begin{tabular}{|c|c|c|c|c|}
\hline No & Nama & Pangkat/Gol & Jabatan Guru & Ket \\
\hline 1 & Indarwani, S,Pd. M.Si & $\begin{array}{c}\text { Pembina Tk.I, } \\
\text { IV/b }\end{array}$ & Kepsek/IPA & \\
\hline
\end{tabular}

\footnotetext{
${ }^{33}$ Muh. Akbar, Warga Desa Temmabarang, Wawancara, pada tanggal 12 Januari 2018.
} 


\begin{tabular}{|c|l|c|c|c|}
\hline 2 & H. Burhanuddin, S.Pd & Pembina Tk.I,IV/b & Guru Kelas V & \\
\hline 3 & Bachtiar, S.Pd. & Pembina IV/b & Guru Penjas & $\begin{array}{c}\text { PD I Kelas } \\
\text { I-VI }\end{array}$ \\
\hline 4 & Indo Asse, S.Pd & Pengatur Muda II/a & Guru Kelas I & \\
\hline 5 & Mussarifah, S.Pd. & Pengatur Muda II/a & Guru Kelas VI & \\
\hline 6 & Muhlis. M, S.Pd.I/GT & - & $\begin{array}{c}\text { Guru Pdd. } \\
\text { Agama Islam }\end{array}$ & $\begin{array}{c}\text { Belas IV, } \\
\text { V, VI }\end{array}$ \\
\hline 7 & Indo Mega, S.Pd./GT & - & Guru Kelas II & \\
\hline 8 & Andi Syahril,S.Pd./GT & - & Guru Kelas III & \\
\hline 9 & Kasmawati, S.Pd./GT & - & Guru Kelas IV & \\
\hline
\end{tabular}

Sumber: Dokumen SDN 147 Temmabarang Kecamatan Penrang Kabupaten Wajo

Berdasarkan tabel di atas, maka dapat diketahui bahwa di SDN 147 Temmabarang terdapat 9 orang tenaga pendidik dengan uraian sebagai berikut: Ibu Indarwani selaku kepala sekolah, Pak H. Burhanuddin selaku guru kelas V, Pak Bachtiar selaku guru penjas, Ibu Indo Asse selaku guru kelas I, Ibu Mussarifah selaku guru kelas VI, Pak Muhlis. M selaku guru pendidikan agama Islam, Ibu Indo Mega selaku guru kelas II, Pak Andi Syahril selaku guru kelas III, dan Ibu Kasmawati selaku guru kelas IV.

Tabel 17

Keadaan Pendidik Sekolah Dasar Negeri 304 Temmabarang

\begin{tabular}{|l|l|l|c|c|}
\hline No & \multicolumn{1}{|c|}{ Nama } & Pangkat/Gol & Jabatan guru & Jenis Guru \\
\hline 1 & Syamsuddin,S.Pd,M.Si & Pembina IV/a & $\begin{array}{c}\text { Guru } \\
\text { Pembina }\end{array}$ & $\begin{array}{c}\text { Guru Bid. } \\
\text { Studi }\end{array}$ \\
\hline 2 & Andi Unru, S. Pd.I & Penata Tk.I/IIIb & $\begin{array}{c}\text { Guru } \\
\text { Pembina }\end{array}$ & $\begin{array}{c}\text { Guru Bid. } \\
\text { Studi }\end{array}$ \\
\hline 4 & Andi Suriatna,S.Pd & II/a & $\begin{array}{c}\text { Guru } \\
\text { Peratama }\end{array}$ & $\begin{array}{c}\text { Guru } \\
\text { Pendais }\end{array}$ \\
\hline 5 & Besse Husniati,S.Pd & GTT & $\begin{array}{c}\text { Guru } \\
\text { Kelas }\end{array}$ & $\begin{array}{c}\text { Guru } \\
\text { Kelas }\end{array}$ \\
\hline 6 & Andi Hajriani,S.Pd & GTT & $\begin{array}{c}\text { Guru } \\
\text { Kelas }\end{array}$ & $\begin{array}{c}\text { Guru } \\
\text { Kelas }\end{array}$ \\
\hline 7 & Andi Asnirawati,S.Pd & GTT & $\begin{array}{c}\text { Guru } \\
\text { Kelas }\end{array}$ & $\begin{array}{c}\text { Guru } \\
\text { Kelas }\end{array}$ \\
\hline 8 & Gustiani & GTT & $\begin{array}{c}\text { Guru } \\
\text { Kelas }\end{array}$ & $\begin{array}{c}\text { Guru } \\
\text { Kelas }\end{array}$ \\
\hline 9 & Aan Kurniawan & GTT & $\begin{array}{c}\text { Guru } \\
\text { Kelas }\end{array}$ & $\begin{array}{c}\text { Guru } \\
\text { Kelas }\end{array}$ \\
\hline
\end{tabular}

Sumber: Dokumen SDN 304 Temmabarang Kecamatan Penrang Kabupaten Wajo

Dari tabel di atas, dapat dilihat dan diketahui bahwa pada SDN 304 terdapat 9 orang tenaga pendidik dengan pembagian tugas masing-masing. Berikut uraian namanama pendidik yaitu; Pak Syamsuddin selaku kepala seolah dan guru bdang studi, $\mathrm{Pa}$ 
Andi Unru selaku guru bdang studi, Ibu Andi Suriatna selaku guru pendais, Ibu Nur Rahmawati selaku guru kelas, Ibu Besse Husniati selaku guru kelas, Ibu Andi Hajriani selaku guru kelas, Ibu Andi Asnirawati selaku guru kelas, Ibu Gustiani selaku guru kelas, dan Pak Aan Kurniawan selaku guru olahraga.

Selanjutnya, Syamsuddin selaku kepala sekolah SDN 304 Temmabarang memberikan komentar bahwa:

Memang benar kalau angka putus sekolah di daerah ini makin tahun makin meningkat. Disamping masalah materi yang sulit untuk diatasi oleh orang tua sehingga yang menjadi akibat fatalnya yaitu anak-anak mereka yang harus mengalah dengan mengorbankan pendidikan mereka, meskipun untuk biaya Pendidikan sudah digratiskan, akan tetapi karena adanya kebutuhan lain yang masih butuh biaya yang cukup besar. Masalah lain yang mendukung adalah kurangnya kesadaran orang tua tentang pentingnya pendidikan untuk masa depan anak-anaknya. ${ }^{34}$

Pernyataan tersebut dipertegas dengan adanya pernyataan dari Besse Husniati selaku tenaga pendidik di SDN 304 Temmabarang yang menjelaskan bahwa:

Orang tua yang merasa diri termasuk dalam kategori miskin lebih memilih anak-anak mereka untuk menganggur dulu, dengan alasan lebih baik bekerja membantu orang tua dulu untuk mengumpulkan biaya pendidikan baru dilanjutkan lagi karena jika trus melanjutkan pendidikan, orang tua akan kewalahan memenuhi semua kebutuhan anak yang diluar tanggungan pemerintah. $^{35}$

Muhammad Kadir merupakan salah satu orang tua peserta didik mmberikan pula komentarnya saat ditemui dikediamannya pada hari Sabtu tanggal 13 Januari 2018, menjelaskan bahwa:

Kami sebagai orang tua melakukan hal yang sangat berat menurut kami karena harus mengorbankan pendidikan ank-anak kami yang seharusnya mengenyam pendidikan malah putus sekolah. Kami sebagai orang tua bukan hanya memiliki 1 tanggungan saja, akan tetapi anak-anak kami yang lain juga butuh biaya, jadi kami mendahulukan anak-anak yang sementara sekolah ditingkat SMP dan SMA. Karena kami juga tidak mau jika anak-anak kami tidak terpenuhi apa yang menjadi kebutuhan mereka. Apa lagi, bagi orang tua yang memiliki anak lebih dari 1 dan tidak memiliki lahan ataupun usaha untuk digarap untuk menghasilkan uang buat biaya sekolah anak-anak kami, biaya sehari-hari serta kebutuhan lainnya. Jika hanya bekerja serabutan, maka untuk memenuhi semua kebutuhan sepertinya sangat sulit. ${ }^{36}$

2. Gambaran tentang kebutuhan sosial, termasuk keterkucilan sosial, ketergantungan, dan ketidakmampuan untuk berpartisipasi dalam masyarakat. Hal ini termasuk pendidikan dan informasi.

Berdasarkan observasi yang dilakukan dilapangan pada tanggal 18 Januari 2018 pukul 15.30, ditemukan bahwa warga masyarakat masih kurang dalam hal pendidikan dan informasi. Berikut hasil wawancara yang diperoleh dari Muhammad Basri selaku kepala dusun Tobulelle yang menyatakan bahwa:

\footnotetext{
${ }^{34}$ Syamsuddin, Warga Desa Temmabarang, Wawancara, pada tanggal 12 Januari 2018.

${ }^{35}$ Besse Husniati, Tenaga Pendidik SDN 304 Desa Temmabarang, Wawancara, pada tanggal 15 Januari 2018

${ }^{36}$ Muhammad Kadir, Warga Desa Temmabarang, Wawancara, pada tanggal 15 Januari 2018.
} 
Selain masalah biaya yang menjadi alasan utama anak-anak harus mengalami putus sekolah, bagi warga kami disini juga terkendala dari segi informasi tentang pentingnya pendidikan. Bagi orang tua yang kurang memahami informasi perkembangan pendidikan serta kurang taunya menggunakan/mencari berita dimedia sosial tentang perkembangan pendidikan dapat menjadikan mereka bermasa bodoh saja. ${ }^{37}$

Hal tersebut juga mendapat komentar dari Indrawani selaku kepala sekolah SDN 147 Temmabarang yang mengungkapkan bahwa:

Karena faktor tidak tau dan tidak mau mencari tau tentang informasi pendidikan, maka orang tua kurang memahami perkembangan pendidikan sekarang. Meskipun adanya sosial media yang bisa diakses oleh semua orang, tetapi untuk melakukannya, tidak ada pengetahuan tentang itu sehingga orang tua tidak peka dengan pentingnya pendidikan. Dengan demikian dampaknya terhadap anak-anak mereka yang harus mengalami putus sekolah. ${ }^{38}$

Pada kesempatan lain juga penulis mewawancarai Andi Ishaka selaku toko masyarakat yang memberikan penjelasan bahwa:

Selain kurangnya informasi tentang pendidikan yang diterima oleh warga, salah satunya juga karena kurangnya perhatian orang tua terhadap pendidikan sehingga anak-anak tidak memperoleh dorongan/motivasi dari keluarga. Dengan demikian, anak-anak terkadang acuh tak acuh untuk menuntut ilmu. Apa lagi warga desa sekarang ini yang lebih diutamakan adalah bagaimana anak-anak bisa mandiri dan menghasilkan uang biar tidak bergantung lagi kepada orang tua. Ada juga yang pemahamannya bahwa sarjana sekarang lebih banyak menganggur dan masih bergantung kepada orang tua meskipun mereka sudah berijazah sarjana. Jadi sekolah tinggi atau rendah bukan jaminan kesuksesan bagi sanak mereka kedepannya. ${ }^{39}$

Walaupun penulis sudah memperoleh informasi dari beberapa responden, akan tetapi, penulis juga ingin mengetahui pendapat dari orang tua dan guru yang ada di Desa Temmabarang. Berikut wawancara dengan orang tua peserta didik yang memberikan tanggapan bahwa:

Kami sebagai orang tua memang kurang memperhatikan tentang informasi pentingnya pendidikan karena kesibukan mencari nafkah sehingga kami hanya taunya anak-anak kami pergi sekolah pada waktunya dan pulang kerumah tepat waktu juga. Untuk perkembangan pendidikan, kami kurang memahami hal tersebut. Ditambah lagi kami tidak mengerti tentang teknologi yang berkembang pesat sekarang yang menjadi akses termudah untuk mengetahui/mencari informasi terbaru tentang pendidikan. ${ }^{40}$

Daeng Macora juga memberikan komentarnya tentang hal tersebut bahwa:

\footnotetext{
Januari 2018. Januari 2018

${ }^{38}$ Indrawani, Kepala Sekolah SDN 147 Desa Temmabarang, Wawancara, pada tanggal 18

${ }^{39}$ Andi Ishaka, toko masyarakat Desa Temmabarang, Wawancara, pada tanggal 21 Januari 2018.

${ }^{40}$ Mellong, Warga dan orang tua peserta didik SDN Desa Temmabarang, Wawancara, pada tanggal 21 Januari 2018.
}

${ }^{37}$ Muhammad Basri, Kepala Dusun Tobulelle Desa Temmabarang, Wawancara, pada tanggal 18 
Orang tua memang tidak pernah mengenal yang namanya mencari informasi dengan teknologi yang pada umumnya orang gunakan. Apalagi kami di desa hanya mengandalkan informasi dari mulut ke mulut. Disamping itu, kami tidak tau menggunakan internet atau semacamnya, sehingga jika anak-anak kami menyampaikan informasi yang mereka dapat dari guru atau teman-teman mereka. Jadi kami masih sangat kurang dalam hal penggunaan teknologi untuk memperoleh informasi khususnya informasi tentang pendidikan. ${ }^{41}$

Di tempat lain juga Ambo Tuo selaku orang tua peserta didik memberikan penjelasan bahwa:

Teknologi memang sangat penting dalam memperoleh informasi, akan tetapi kendala bagi kami orang tua yaitu sangat kesulitan dalam mempelajari cara menggunakan teknologi ataupun mengakses internet dalam memperoleh informasi tentang pentingnya pendidikan dan perkembangan pendidikan.Jadi untuk menyesuaikan diri dalam kalangan masyarakat yang mahir dalam hal penggunaan teknologi untuk memperoleh informasi, sudah termasuk hal sulit. ${ }^{42}$ Tidak ketinggalan pula komentar dari Laulang yang menjelaskan bahwa:

Tidak bisa dipungkiri bahwa teknologi sangatlah penting terutama untuk mengetahui perkembangan pendidikan demi kemajuan anak-anak kami. Terkadang kami sebagai orang tua merasa minder dengan kurangnya pengetahuan tentang teknologi. Hal ini bukan karena disengaja, akan tetapi banyak faktor yang menjadi penyebabnya yaitu dulu, akses ke desa tempat tinggal kami masih sulit, kurangnya perhatian terhadap informasi yang diterima dari orang lain dan lebih mementingkan bekerja untuk keluarga daripada mnjemput informasi yang selalu berkembang. Dan yang paling utama sekarang adalah karena usia dan sulitnya menggunakan alat untuk mencari informasi tentang pendidikan. Dengan demikian, anak-anak kami ikut terkena imbasnya yaitu kami sulit membimbing mereka karena mereka lebih mengetahui menggunakan teknologi dalam mencari informasi. ${ }^{43}$

Hal tersebut dipertegas oleh Mussarifah salah satu tenaga pendidik di SDN 147

Temmabarang, yaitu:

Kekurangan untuk anak-anak didik kami disini adalah masih kurangnya teknologi untuk memperoleh informasi. Karena jam tatap muka dengan guru tergolong singkat, makanya guru sebenarnya tidak sempat untuk selalu memberikan pemahaman tentang pentingnya penggunaan teknologi dalam menggali informasi khususnya tentang pendidikan agar kelak anak-anak punya bekal pengetahuan tentang teknologi agar mereka tidak kaku jika berada ditengah teman-temannya yang sudah mahir. Akan tetapi, kami terkendala karena waktu yang terbatas dan orang tua mereka yang masih tergolong belum mengetahui teknologi. ${ }^{44}$

\footnotetext{
${ }^{41}$ Daeng Macora, Warga Desa Temmabarang, Wawancara, pada tanggal 21 Januari 2018.

${ }^{42}$ Ambo Tuo, Warga dan Orang Tua Peserta Didik Desa Temmabarang, Wawancara, pada tanggal 21 Januari 2018.

${ }^{43}$ Laulang, Warga dan Orang Tua Peserta Didik Desa Temmabarang, Wawancara, pada tanggal 21 Januari 2018. 2018.

${ }^{44}$ Mussarifah, Tenaga Pendidik SDN 147 Temmabarang, Wawancara, pada tanggal 23 Januari
} 


\section{Potret Kemiskinan dan Anak Putus Sekolah di \\ Desa Temmabarang...}

Pada sekolah lain juga diperoleh hasil wawancara dari salah satu tenaga pendidik yaituNur Rahmawati yang menyatakan bahwa:

Pengetahuan teknologi bagi anak didik memang sangat penting, untuk itu kita perlu membrikan pengetahuan tersebut dengan tetap mengawasi mereka agar pengetahuan yang diperoleh tidak disalah gunakan untuk hal-hal yang kurang bermanfaat dan dapat menyimpang dari kebutuhan yang sewajarnya. ${ }^{45}$

3. Gambaran tentang kurangnya penghasilan dan kekayaan yang memadai.

Berdasarkan observasi yang dilakukan pada tanggal 21 Januari 2018 pukul 16.00, ditemukan bahwa ternyata masalah penghasilan dan kekayaan dapat mempengaruhi tingkat putus sekolah. Berikut hasil wawancara dengan kepala Dusun Bakke-bakke bapak Andi Tamrin yang mengungkakan bahwa:

Jika masalah penghasilan dan kekayaan, itu relatif karena jika hasil pertanian tidak bisa ditebak berapa yang akan diperoleh dalam setiap panen karena persawahan disini cuma sawah tadah hujan, bukan sawah irigasi. Jadi tergantung bagaimana mereka mengelolah keuangan keluarga mereka dan apa saja yang menjadi kebutuhan mereka. Nah, jika dikaitkan dengan pendidikan anak-anak mereka, sebenarnya penghasilan dan kekayaan bukanlah faktor penghambat untuk anak-anak untuk menuntut ilmu, tergantug bagaimana orang tua mereka memberikan motivasi dan dorongan yang intens agar anak-anak mereka mengutamakan sekolah/pendidikan dengan harapan bisa mendapatkan ilmu yang brmanfaat. ${ }^{46}$

Selanjutnya, pada tanggal 21 Januari 2018 penulis kembali mewawanca seorang toko masyarakat yaitu Andi Ishaka yang memberikan pernyataan bahwa:

Karena didesa kami ini tidak ada irigasi, maka banyak dari warga disini yang memilih untuk merantau untuk memenuhi kebutuhan keluarga, termasuk memenuhi biaya pendidikan anak-anaknya. Hal ini disebabkan karena tidak semua warga memiliki sawah untuhk digarap. Akan tetapi ada juga warga yang memiliki sawah dan tambak tapi jarak tambak dari tempat tinggal cukup jauh sehingga jika untuk menggarap tambak, maka penduduk harus tinggal di tempat tambak mereka. Ini dilakukan untuk memenuhi biaya pendidikan anak mereka agar terhindar dari putus sekolah, karena ada juga yang menginginkan anak mereka sekolah dengan semua harus serba terpenuhi tetapi ada juga yang menyekolahkan anak-anak mereka betul-betul agar anak mereka mendapatkan ilmu dan pendidikan meskipun harus bersekolah dengan biaya seadanya. Nah, disinilah terkadang ditemukan anak-anak yang putus sekolah jika terlalu dituruti keinginannya untuk melengkapi semua kebutuhannya, maka jika sedikit saja yang tidak terpenuhi, maka anak tersebut sudah ciut untuk bersekolah karena terbiasa dengan perlengkapan yang serba ada. Padahal sebenarnya anakanak harusnya diajarkan untuk hidup sederhana karena penghasilan dan kekayaan itu tentatif, jadi tidak bisa dijadikan tolak ukur dalam hal pendidikan. $^{47}$

\footnotetext{
${ }^{45}$ Nur Rahmawati, Tenaga Pendidik SDN 304 Temmabarang, Wawancara, pada tanggal 24 Januari 2018.

${ }^{46}$ Andi Tamrin, Kepala Dusun Bakke-bakke Desa Temmabarang, Wawancara, pada tanggal 21 Januari 2018

${ }^{47}$ Andi Ishaka, toko masyarakat Desa Temmabarang, Wawancara, pada tanggal 21 Januari 2018.
} 

bahwa:

Hal tersebut di pertegas oleh orang tua peserta didik Mellong yang menjelaskan

Kalu saya pribadi, saya tidak terlalu memikirkan masalah penghasilan berapa dan kekayaan berapa sehingga saya hanya menekankan kepada anak saya untuk tetap bersekolah karena pendidikan menurut saya sangat penting dari pada harta. Jadi karena kami dari keluarga yang sederhana, maka kami memprioritaskan pendidikan karena pendidikan adalah harta kekayaan bagi kami. $^{48}$

Orang tua lain memberikan komentarnya yang mereka jelaskan saat wawancara yaitu:

Memang betul harta kekayaan bukan ukuran dalam dunia pendidikan akan tetapi, kalu saya itu berkeinginan memberikan yang terbaik untuk pendidikan anak saya dengan jalan memenuhi semua kebutuhan pendidikan anak-anakagar kami tidak mngalami yang namanya put us sekolah hanya karna faktor adanya kebutuhan yang tidak terpenuhi. ${ }^{49}$

Abdul Karim juga berkomentar bahwa:

Yang harus diprioritaskan adalah bagaimana anak-anak bisa terus bersekolah sampai kejenjang yang lebih tinggi. Jika tolak ukurnya adalah penghasilan dan kekayaan, maka anak-anak tidak akan memperhatikan kewajibannya untuk belajar sehingga dampaknya adalah dapat terjadi putus sekolah. ${ }^{50}$

Pada saat yang bersamaan, Ambo Angka juga membrikan penjelasan bahwa:

Selama anak-anak kami bersekolah, kami belum merasa begitu khawatir untuk kebutuhannya karena masih di tingkat SD sebab anak masih tinggal bersama kami dan jarak ke sekolah cukup dekat sehingga untuk biaya transpor dan uang jajan sudah tidak perlu lagi. Kalau berbicara masalah kekayaan dan penghasilan, tidak bisa juga kita nafikkan karena tanpa adanya penghasilan maka anak-anak orang tua tidak bisa memberikan keperluan yang memang harus menggunakan materi meskipun sekolah sudah gratis karena contoh kecilnya, jika sepatu dan tasnya rusak, pasti anak-anak akan meminta untuk digantikan dengan yang baru dan sebagai orang tua pasti tidak tega mlihat anaknya bersekolah dengan kondisi barang yang sudah rusak dan tidak layak pakai. Dengan begitu, anggaran tentang enghasilan dan kekayaan mungkin bisa dinomor tigakan karena jika tidak, maka dampak terburuknya adalah anak-anak akan mengalami putus sekolah. Nah untuk saya pribadi, yang menjadi kekhawatiran utama adalah jika anak-anak putus sekolah hanya karena persoalan seperti itu, padahal orang tua masih bisa berusaha. ${ }^{51}$ bahwa:

Selanjutnya, Burhanuddin selaku tenaga pendidik memberikan tanggapannya

Jika melihat secara umum, sebenarnya tidak akan ada anak yang terus bersekolah jika tolak ukurnya adalah kekayaan. Karena pada dasarnya, jika

\footnotetext{
${ }^{48}$ Mellong, Warga dan orang tua peserta didik SDN Desa Temmabarang, Wawancara, pada tanggal 21 Januari 2018.

${ }^{49}$ Paramata, Warga dan orang tua peserta didik SDN Desa Temmabarang, Wawancara, pada tanggal 21 Januari 2018.

${ }^{50}$ Abdul Karim, Warga dan orang tua peserta didik SDN Desa Temmabarang, Wawancara, pada tanggal 25 Januari 2018.

${ }^{51}$ Ambo Angka, warga dan orang tua tenaga pendidik SDN Desa Temmabarang, Wawancara, pada tanggal 25 Januari 2018.
} 
kekayaan yang menjadi ujung tombak untuk anak-anak tetap bersekolah, maka sulit bagi orang tua di daerah ini untuk menyekolahkan anak-anaknya. Kenapa, karena makin banyaknya harta yang dimiliki, maka akan banyak juga kebutuhan dan tidak bisa dipungkiri jika uang ada, maka hal yang tidak begitu penting akan dianggap juga sebagai kebutuhan. Akan tetapi, kami senantiasa menghimbau kepada orang tua siswa dalam setiap pertemuan dengan orang tua bahwa, faktor utama untuk mengurangi angka putus sekolah bagi anak tingkat SD itu adalah dorongan, motivasi dan semangat yang selalu baru untuk anakanaknya. Dengan demikian, semangat anak-anak juga akan bangkit dan tidak peduli lagi dengan kelengkapan sekolah yang tidak memadai dari orang tua. Nah inilah yang diupayakan sebenarnya.

Andi Unru selaku pendidik di SDN 304 memberikan penjelasan bahwa:

Untuk melatih anak-anak menghadapi hidupnya kedepan, sebenarnya meskipun orang tua yang memiliki penghasilan dan kekayaan cukup untuk memberikan yang terbaik yaitu dengan memenuhi semua permintaan mereka agar tetap giat bersekolah, sebenarnya hal yang kurang mendidik karena penghasilan itu tidak bisa dipastikan karena tidak menentu. Ya... tergantung rezki dari Allah. Jadi meskipun orang tua tergolong kaya, anak-anak juga harus diajarkan untuk tetap hidup sederhana, karena anak-anak jika diberikan lebih, akan menjadi sesuatu yang dapat membuat mereka pamer dan sombong. Namanya anak-anak itu, masih belum ada pemikiran untuk halhal seperti itu, makanya orang tualah yang seharusnya menjadi ujung tombak agar anak-anak mereka tetap bisa bersekolah dengan sederhana, dan hal ini juga tidak terlepas dari bantuan para guru-guru di sekolah. ${ }^{52}$

\section{PENUTUP}

Berdasarkan paparan di atas, maka dapat disimpulkan bahwa potret kemiskinan dan anak putus sekolah di desa Temmabarang Kecamatan Penrang Kabupaten Wajo karena masih minimnya lahan yang bisa digarap untuk pertanian oleh masyarakat sehingga tidak memiliki penghasilan tetap, keberadaan lahan persawahan tidak menjamin karena tidak adanya irigasi, kebutuhan yang semakin hari semakin meningkat, dan tidak memiliki modal untuk berwirausaha serta kurangnya pengetahuan tentang pentingnya pendidikan.

${ }^{52}$ Andi Unru, Tenaga Pendidik SDN 304 Temmabarang, Wawancara, pada tanggal 25 Januari 2018. 


\section{DAFTAR PUSTAKA}

Alfian, Kemiskinan Struktural: Suatu Bunga Rampai (Jakarta: Penerbit Yayasan Ilmuilmu Sosial dan HIPIS, 2000), h. 64.

Amirullah, dan Imam Hardjanto, Pengantar Bisnis, Edisi Pertama Yogyakarta: Graha Ilmu, 2005.

Baharuddin, Psikologi Pendidikan: Reflektif Teoritis Terhadap Fenomena, Yogyakarta: Ar-ruzz Media, 2007.

Departemen Pendidikan dan Kebudayaan, Kamus Besar Bahasa Indonesia Jakarta: Balai Pustaka, 1990), h. 587.

Fauzi, Akhmad, Ekonomi Sumberdaya Alam dan Lingkungan: Teori dan Aplikasi (Jakarta: PT. Gramedia Pustaka Utama, 2004.

Halim, Abd., Politik Lokal; Pola, Aktor \& Alur Dramatikalnya, Yogyakarta: LP2B, 2014.

Ihsan, Fuad, Dasar-Dasar Kependidikan, Jakarta: Rineka Cipta, 2008.

Indonesia/https://pendidikberpena.wordpress.com/2014/12/05/catatan-burampendidikan-vs-pendidkan-berkualitas/

Krisdinanto, Nanang, "Pierre Bourdieu, Sang Juru Damai", Jurnal KANAL, Vol. 2 No. 2 Maret 2014.

Munawwir, Ahmad Warson, Kamus al-Munawwir Arab-Indonesia Terlengkap, Cet. XXV; Surabaya: Pustaka Progressif, 2002.

Nugroho, Ardi, Listyawan, Pengaruh Modal Usaha Yogyakarta: Pustaka Pelajar, 2011.

Olgar, Maulana Musa Ahmad, Mendidik Anak Secara Islami, Terjemahan Supriyoto Abdullah Hidayat Yogyakarta: Ash-Shatt, 2000.

Osborn dan Plastrik. Manajemen Sumber Daya Mausia Yogyakarta: BPFE, 2002.

Qardhawi, Yusuf, Kiat Islam Mengentaskan Kemiskinan Jakarta: Gema Insani Press, 1995. 
Rachbini J, Didik. Politik Ekonomi Baru Menuju Demokrasi Ekonomi Jakarta: Grasindo, 2001. 1995.

- Negara dan Kemiskinan Daerah Jakarta: Pustaka Sinar Harapan,

Ritzer, George \& Douglas J. Goodman, Teori Sosiologi; Dari Teori Sosiologi Klasik sampai Perkembangan Mutakhir Teori Sosial Postmodern (Yogyakarta: Kreasi Wacana, 2009.

Sayuti, Hasibuan,. Ekonomi Sumberdaya Manusia: Teori dan Kebijakan, Jakarta: Pustaka LP3ES Indonesia, 1996.

Siagian, Sondang P., Kiat Meningkatan Produktifitas Kerja Jakarta: Rineka Cipta, 2002.

Suharto. E, Membangun Masyarakat Memberdayakan Rakyat, Bandung: Refika Aditama, 2008.

Sukardi, Dewa Ketut. Psikologi Pemililhan Karier, Jakarta : PT. Rineka Cipta, 2004.

Sukirno, Sadono,. Teori Mikro Ekonomi Cetakan Keempat Belas Jakarta: Rajawali. Press, 2004.

Sumodiningrat, G. Kemiskinan: Teori, Fakta dan Kebijakan Jakarta: IMPAC, 2000.

Suparlan, P, Kemiskinan di Perkotaan: Bacaan untuk Antropologi Perkotaan, Jakarta: Sinar Harapan, 2000.

Suparlan, Parsudi, Kemiskinan di Perkotaan Jakarta: Yayasan Obor, 1993.

Tambunan, T. Perekonomian Indonesia Sejak Orde Lama Hingga Pasca Krisisi, Jakarta: Pustaka Quantum, 2006.

Yusuf, A Murni, Kemiskinan dan Kebutuhan Pokok(Jakarta: CV. Rajawali, 2006.

\section{Sumber Wawancara}

Andi Page, Kepala Desa Temmabarang, Wawancara, pada tanggal 9 Januari 2018.

Nyompa, Kepala Dusun Mattirowalie, Wawancara, pada tanggal 11 Januari 2018.

Dg. Mamala, Warga Desa Temmabarang, Wawancara, pada tanggal 12 Januari 2018.

Muh. Akbar, Warga Desa Temmabarang, Wawancara, pada tanggal 12 Januari 2018.

Syamsuddin, Warga Desa Temmabarang, Wawancara, pada tanggal 12 Januari 2018.

Besse Husniati, Tenaga Pendidik SDN 304 Desa Temmabarang, Wawancara, pada tanggal 15 Januari 2018.

Muhammad Kadir, Warga Desa Temmabarang, Wawancara, pada tanggal 15 Januari 2018.

Muhammad Basri, Kepala Dusun Tobulelle Desa Temmabarang, Wawancara, pada tanggal 18 Januari 2018.

Indrawani, Kepala Sekolah SDN 147 Desa Temmabarang, Wawancara, pada tanggal 18 Januari 2018. 
Andi Ishaka, toko masyarakat Desa Temmabarang, Wawancara, pada tanggal 21 Januari 2018.

Mellong, Warga dan orang tua peserta didik SDN Desa Temmabarang, Wawancara, pada tanggal 21 Januari 2018.

Daeng Macora, Warga Desa Temmabarang, Wawancara, pada tanggal 21 Januari 2018.

Ambo Tuo, Warga dan Orang Tua Peserta Didik Desa Temmabarang, Wawancara, pada tanggal 21 Januari 2018.

Laulang, Warga dan Orang Tua Peserta Didik Desa Temmabarang, Wawancara, pada tanggal 21 Januari 2018.

Mussarifah, Tenaga Pendidik SDN 147 Temmabarang, Wawancara, pada tanggal 23 Januari 2018.

Nur Rahmawati, Tenaga Pendidik SDN 304 Temmabarang, Wawancara, pada tanggal 24 Januari 2018.

Andi Tamrin, Kepala Dusun Bakke-bakke Desa Temmabarang, Wawancara, pada tanggal 21 Januari 2018.

Andi Ishaka, toko masyarakat Desa Temmabarang, Wawancara, pada tanggal 21 Januari 2018.

Mellong, Warga dan orang tua peserta didik SDN Desa Temmabarang, Wawancara, pada tanggal 21 Januari 2018.

Paramata, Warga dan orang tua peserta didik SDN Desa Temmabarang, Wawancara, pada tanggal 21 Januari 2018.

Abdul Karim, Warga dan orang tua peserta didik SDN Desa Temmabarang, Wawancara, pada tanggal 25 Januari 2018.

Ambo Angka, warga dan orang tua tenaga pendidik SDN Desa Temmabarang, Wawancara, pada tanggal 25 Januari 2018.

Andi Unru, Tenaga Pendidik SDN 304 Temmabarang, Wawancara, pada tanggal 25 Januari 2018. 